\title{
Adoption of Environmental Principles in Forest Legislation of Malaysia: An Appraisal
}

\author{
Adzidah binti Yaakob ${ }^{1}$, Nurfadhilah binti Che Amani ${ }^{2}$ \\ ${ }^{I}$ (Faculty of Syariah and Law, Universiti Sains Islam Malaysia, Malaysia) \\ ${ }^{2}$ (Faculty of Syariah and Law, Universiti Sains Islam Malaysia, Malaysia)
}

\begin{abstract}
This paper examines Malaysia forest legislation and Environmental Law principles in comprehending the present forest issues particularly in Peninsular Malaysia. A number of Environmental Law principles recognized at the international level are studied to perceive its adoption in the forest legislation of Peninsular Malaysia. The National Forestry Policy 1978 (Revised 1992), the National Forestry Act 1984, the National Policy on Biological Diversity and the Malaysia Plan along with the Environmental Law principles such as sustainable development, precautionary principles, polluter pays and intergenerational equity are examined and discussed to satisfy the premise of this study. Thus, it is evidently significant to adopt these recognised principles into forest legislation in safeguarding the sustainability of forest in Malaysia.
\end{abstract}

Keywords : environmental law principles, forest conservation, law, Malaysia, policy

\section{INTRODUCTION}

It is known that Malaysia is home to at least 12,000 flowering plants, 2,650 tree species, 890 tree species of timber size, 408 marketable timber species, 400 species of palms, 145 species of ginger, 70 species of bamboo, 600 species of fern and 700 species of fungus (Zakaria, 2007). Further, it is noted that Malaysia has far more plant species than the temperate countries, i.e. European countries, USA and Canada. Thus it is a great challenge to Malaysia to manage its forests and species of plants according to the required level. In view of its climatic conditions, Malaysia indeed needs to have its own approaches to managing and conserving its forests and species of plants, as the approaches applied in temperate countries are not necessary suitable for Malaysian conditions and interests (Zakaria, 2007).

Forests in Malaysia are now decreasing as a result of clearance of the forested land for the purpose of development, mostly in agricultural activity (Thang, 2002 and Yaakob, 2014). Despite the need to boost the country's economy, forests should be maintained for substantial reasons. Forest issues have been highlighted since the early 90s when the world started to gain new insights into forest in terms of environmental concerns. This has also affected Malaysia's approach to forest where the government, as the representative of a member state of the International Convention, needs to draft forest rules and policies to suit the aims of the international perspective on forest.

This study applies general doctrinal approach on the Peninsular Malaysia legal instruments and literature on forest conservation. Apart from the study on law and policy pertaining to the International and Malaysian forest legal framework, a study of the significant related Environmental Law principles and understanding is also emphasised to fully understand the nature and concept of law in context.

It is believed that highlighting related forest provisions and the internationally recognized Environmental Law principles will provide a better understanding of the global perspective on forests' influence, and the approach and practices of Peninsular Malaysia in dealing with the issue of forest conservation.

\section{MALAYSIA AND INTERNATIONAL COMMITMENT IN CONSERVING FOREST}

Forest covers about $30 \%$ of the world's land area, i.e. an estimated $6200 \mathrm{~m}^{2}$ (Green Facts, 2011). With this percentage, forest has undeniably played a great role and function for generations. Among other environmental substances, forest is one of the focal areas to be conserved and preserved. The largest percentage of the world's forest area is in Europe due to the huge amount of forest situated in the Russian Federation (FAO, 2011). The Asian region accounts for $15 \%$ of the world's forest while Oceania has $5 \%$, Africa and North and Central America have 17\% each, South America has 21\% and Europe has 25\% (MTC, 2005 and Mazwin, 2007).

Even though the percentage of forest coverage is relatively small, forest is considered to have been included in international legal regimes among other environmental substances for participating countries to observe and comprehend. A number of international forest agreements and conventions to which Malaysia is a 
party have been promulgated, for instance the RAMSAR Convention on Wetlands ${ }^{1}$, Convention Concerning the Protection of the World's Cultural and Natural Heritage ${ }^{2}$, Convention on International Trade of Endangered Species of Wild Flora and Fauna (CITES) ${ }^{3}$, United Nations Framework Convention on Climate Change $\left(\mathrm{UNFCC}^{4} \text { and Kyoto Protocol }{ }^{5} \text {, Convention on Biological Diversity (CBD }\right)^{6}$, United Nations Forum on Forests (UNFF) $)^{7}$, International Tropical Timber Agreement (ITTA $)^{8}$, and the Non-legally Binding Instrument on All Types of Forests ${ }^{9}$. Forest issues have been highlighted not only in a series of international agreements and conventions but also through discussions in forums and also through forest partnerships between countries.

\section{The Environmental Principles Relating to Forest Conservation}

In order to meet the objective of the study, it is important, in this particular section, to highlight several principles which are most connected to forest conservation. Hence, drawing on the earlier international law on forest, there are several environmental principles that relate to forest conservation that are sustainable development, precautionary principle, polluter pays and also intergenerational equity. These internationally recognized environmental principles are significant in term of its anticipated effective outcome for forests survival.

The first principle is on sustainable development; this principle has its origin in the Stockholm Declaration in its Principle 2 which states that;

The natural resources of the earth, including the air, water, land, flora and fauna and especially representative samples of natural ecosystems, must be safeguarded for the benefit of present and future generations through careful planning or management, as appropriate (Sands and Galizzi, 2004).

This principle of sustainable development is also highlighted in Principle 2 of the Rio Declaration;

States have, in accordance with the Charter of the United Nations and the principles of International law, the sovereign right to exploit their own resources pursuant to their own environmental and developmental policies, and the responsibility to ensure that activities within their jurisdiction or control do not cause damage to the environment of other States or of areas beyond the limits of national jurisdiction (Sands and Galizzi, 2004).

The term 'sustainable development' was reiterated in the Rio Declaration, thus showing the significance of harmonizing development with environment. The principle deals with vital issues of environmental degradation as the main concern of the principle is about sustaining natural resources which have been excessively used by the proprietor. The resources need to be sustained for the benefit of current and future generations (McEldowney and Sharron, 2001). Thus, the principle states that, in order to preserve natural resources for future generations, it is important to foresee the feasibility of the remainder of the natural resources.

Thus, based on the principle, there is a need to foresee the trends of forest biodiversity in Malaysia on the ground that Malaysia's forest resources are being depleted because of the strong consideration given to economic and business development. The urgent action needed to sustain forest biodiversity in Malaysia is highly significant due to its multiple functions. It seems that the government of Malaysia is cognisant with the aim of the sustainability principle but the extent to which it has been implemented is another matter, as the forest is apparently being cleared in the name of economic growth.

The second principle is the 'precautionary principle'. This relates to preventive action to avoid environmental risk or threat (John, 2001 and Sharma, 2009). This principle has been derived from the 1987 North Sea Declaration and also indirectly from a number of Conventions and resolutions preceding it (Sheridan and Lavrysen, 2002). This idea is clearly stated under Principle 15 of the Rio Declaration as follows;

\footnotetext{
${ }^{1}$ Convention on Wetlands of International Importance especially as Waterfowl Habitat, opened for signature 2 Feb. 1971, UNTS I-14583 (entered into force 21 Dec. 1975). Malaysia ratified in Feb. 1971.

${ }^{2}$ Convention concerning the Protection of the World Cultural and Natural Heritage, opened for signature 16 June 1972, UNTS 15511 (entered into force 17 Dec. 1975). Malaysia ratified on 7 Dec. 1988.

${ }_{3}^{3}$ Convention on International Trade in Endangered Species of Wild Fauna and Flora, opened for signature 3 Mar. 1973, UNTS I-14537 (entered into force 1 July 1975). Malaysia ratified CITES in 1977.

${ }^{4}$ United Nations Framework Convention on Climate Change, opened for signature 9 May 1992, UNTS 30822 (entered into force 21 Mar. 1994). Malaysia ratified UNFF on 13 July 1994.

${ }^{5}$ Kyoto Protocol to the United Nations Framework Convention on Climate Change, opened for signature 11 Dec. 1997, UNTS 30822 (entered into force 16 Feb. 2005). Malaysia ratified Kyoto Protocol on 4 Sep. 2002.

${ }^{6}$ Convention on Biological Diversity, opened for signature 5 June 1992, UNTS 30619 (entered into force 29 Dec. 1993). Malaysia ratified CBD in June 1994.

${ }^{7}$ Report of the fourth session of the Intergovernmental Forum on Forests, UN ESCOR, $4^{\text {th }}$ sess, UN Doc E/2000/L.32 (2000).

${ }^{8}$ International Tropical Timber Agreement, opened for signature 3 Apr. 2006, UNTS 49197 (entered into force 7 Dec. 2011). Malaysia ratified on 28 Sep. 2007.

${ }^{9}$ Non-legally binding instrument on all types of forests, UN GAOR, $62^{\text {nd }}$ sess, UN DOC A/RES/62/98 (2007). Malaysia adopted this forest instrument in 2007.
} 
In order to protect the environment, the precautionary approach shall be widely applied by States according to their capabilities. Where there are threats of serious or irreversible damage, lack of full scientific certainty shall not be used as a reason for postponing cost-effective measures to prevent environmental degradation (Sands and Galizzi, 2004).

Therefore, for this particular study, the principle can be used to assess a proprietor's need to cut down trees in a forest area. Whether a large area of forest can be protected by applying and implementing the principle is debatable. The application of this principle, which is significant for forest conservation, can also be seen in Principle 17 of the Rio Declaration which states the following;

Environmental impact assessment, as a national instrument, shall be undertaken for proposed activities that are likely to have a significant adverse impact on the environment and are subject to a decision of a competent national authority (Sands and Galizzi, 2004).

This principle is seen to be implemented in the Environmental Impact Assessment Guidelines for Forestry (MOSTE, 1998). According to these guidelines, interaction between the project proponent, the project managers, forestry consultants and the EIA consultants' team is necessary to ensure the smooth running of the preparation of the EIA documents (MOSTE, 1998). This assessment process must be conducted with great integrity as it affects the quality of the environment and also reflects the related agencies' accountability. Thus, the EIA process can be regarded as putting the precautionary approach into practice in order to predict the detrimental effects on forest environment caused by development projects.

Thus it can be clearly seen in the Declaration that the Environmental Principles have been expanded to include every aspect of sustaining forest.

Another environmental principle that is strongly related to forest conservation is the 'polluter pays' principle which originated in the Organisation for Economic Co-operation and Development in a Recommendation of 1972 (Sheridan and Lavrysen, 2002). Principle 16 of the Rio Declaration has also underlined the principle as follows;

National authorities should endeavor to promote the internalization of environmental costs and the use of economic instruments, taking into account the approach that the polluter should, in principle, bear the cost of pollution, with due regard to the public interest and without distorting international trade and investment (Sands and Galizzi, 2002).

The 'polluter pays' principle can be seen to have been applied in the NFA in terms of punishments for forest offenders. The NFA, among other legislation, was amended in 1993 to increase the size of the fine for the offence of trespassing and violating forest environment, for instance illegal logging. The penalty has been increased from RM2, 000 to RM50, 000 or RM500, 000 according to the degree of the offence (Forestry Department, 2007).

Intergenerational equity is another environmental principle which could relate to public rights in the forest. It refers to the rights of future generations to receive natural wealth as it has been passed to the present generation from the previous generation (Beder, 1996).

The intergenerational equity principle can be seen in two different ways: from the perspective of 'weak sustainability' and from that of 'strong sustainability' (Beder, 1996). Weak sustainability refers to the ability of future generations to create wealth as experienced by the present generation (Beder, 1996). This also means that future generations would be adequately compensated for any environmental deterioration to enable them to create wealth by alternative means (Beder, 1996). Strong sustainability, however, means seeing the environment as an irreplaceable substance that not even man-made wealth can restore and suggests that a degraded environment cannot be inherited by future generations even if they are supplied with extra means of wealth generation (Beder, 1996).

Nevertheless, it is difficult to ensure and measure the implementation of actions by the present generation required to meet their responsibilities to future generations (Weiss, 2012). Therefore, any problems occurring should be seen as long-term issues rather than short-term issues (Weiss, 2012). Thus, there should be several adjustments to institutions, economic incentives and legal instruments, as well as public awareness and a strong political will, all of which should be in line with the implementation of responsibilities to future generations from a long-term perspective (Weiss, 2012).

The following section determines the adoption of the aforementioned environmental principles in the Malaysia's legal content on forest conservation.

\section{ADOPTION OF ENVIRONMENTAL LAW PRINCIPLES FOR THE PURPOSE OF FOREST CONSERVATION IN PENINSULAR MALAYSIA}

It is undeniable that the government of Malaysia is in the process of developing efforts to prevent its forests from being totally depleted. The National Forestry Act and its Policy are their initial legal response to the 
issue of forests in Peninsular Malaysia. This Act and Policy are based on the Federal Constitution ${ }^{10}$. It is to be noted that the East Malaysia of Sabah and Sarawak has respectively owned forest legislation.

Forest conservation has been a substantial part of the environmental agenda for both Malaysia's legal regime and the international legal regime. The basis of forest jurisdiction is laid down in the Federal Constitution. Forest in Peninsular Malaysia is governed by the National Forestry Policy 1978 (Revised 1992) ${ }^{11}$ and the National Forestry Act $1984^{12}$. Besides these, there are several other policies that are mostly related to the issue of forest conservation, for instance The Environmental Quality (Prescribed Activities) (Environmental Impact Assessment) Order $1987^{13}$, the National Policy on Biological Diversity $1998^{14}$ and the Malaysian Plan. From these Plans, we can clearly see the shifting role of forest from a matter of commodity to environmental substance as a result of public awareness of the importance of sustaining the forest. The plans however, are not exhaustive as the law and policy are progressing as the outcome of the raising of environmental awareness among policymakers and the public at large.

The concern about environmental issues in the forest has in fact existed since time immemorial even though, at that particular time, forest had been cleared for the purpose of developing new areas and cities. In 1926, the Secretary General had explained to the Federal Council about the government policy on forestry. He explained that the Federated Malay States and the Straits Settlements needed to be independent in wood resources, fuel wood and coal wood. He further explained that, in order to achieve this aim, all states must persist in conserving forested land (Forest Manual, 2003).

The 1978 National Forest Policy (NFP) is more comprehensive in terms of strengthening the concept of sustainable forest management. In 1992, the NFP was amended to cater for the needs of classifying Permanent Reserve Forest (PRF) and eight additional forest fields (Forest Manual, 2003).

The development of the NFP is seen as quite unrealistic if compared to the real situation in the forest. It seems that all forest-related matters were listed in the NFP; however, the main concern was the extent to which forest could be maintained. Therefore, the total area of forest loss was hardly replaced and, even if it was replaced, the forest environment could not be restored. To conserve the damaged forest, the forest conservator would carry out conservation methods with an allocated budget (Forest Annual Report, 2007) although the allocated budget was never able to repair the massive forest loss. Nonetheless, the NFP should be carefully revised as the NFA will follow the revised framework of the policy.

The intergenerational equity principle can be seen in the concept of sustainable development as this concept gives priority to sustaining the present benefits for future generations to enjoy. Thus, in terms of forestry, sustainable forest management (SFM) is seen to be best suited to the concept of the principle. The concept of SFM is clearly stated under the NFP which stressed the sustainability concept of forest harvesting; this method takes into account a specific number of trees that must remain after the harvesting process in order to avoid the complete destruction of the forest harvesting area. Nonetheless, the concept of SFM has been seen to give priority to economy rather than environmental and societal needs where $40.7 \%$ of the Permanent Reserved Forest in Peninsular Malaysia has been allocated for production forest in 2012 (www.forestry.gov.my, 2014). However, should the SFM is diligently practised, the benefits of forest will be sustained for future generations to appreciate.

The National Forestry Act 1984 (the NFA) was intended to standardize all Peninsular Malaysia states' forestry laws. In 1993, several areas of the former NFA were amended with higher penalties and heavier punishments prescribed to punish the forest criminal or wrongdoer. However, the amended penalty does not serve deterrence purpose especially to timber tycoon. Indeed, the large amount of penalty could not even replace the damage that has already been done to the forest environment. The increased penalty should serve deterrence purpose of punishment particularly to those people in the industry. Among other amended provisions is burden of proof, which has been shifted from the prosecutor to the accused (MTC, 2005). Therefore, the process of proving forest crimes in court will be easier for the prosecutor than it was under the former provisions of the NFA (Forest Manual, 2003). Other than that, power to enforce the law has also been delegated to soldiers in ensuring forest security. Incentives and witness protection schemes are also available for those who inform about forest crimes. The amended provisions are specifically designed to upgrade the NFA, specifically in the areas of forest security and sustainable management (Forest Manual, 2003 and Said, 2007). Despite the amended provisions, the replacement of the excised forest area is not mandatory and there is no penalty

\footnotetext{
${ }^{10}$ Laws Of Malaysia Federal Constitution, The Commissioner Of Law Revision, Malaysia Under The Authority Of The Revision Of Laws Act 1968 In Collaboration With Percetakan Nasional Malaysia Bhd 2006.

${ }^{11}$ The National Forestry Policy 1978 (Revised 1992), Approved by the National Forestry Council on 19 April 1978, Malaysia, Forestry Department Peninsular Malaysia.

${ }^{12}$ Laws of Malaysia, The National Forestry Act 1984 (Act 313).

${ }^{13}$ Laws of Malaysia, The Environmental Quality (Amendment) Act 2012 (Act A1441) Environmental Quality (Prescribed Activities) (Environmental Impact Assessment) Order 1987.

${ }^{14}$ The National Policy on Biological Diversity, Approved on 16 Apr. 1998, the Ministry of Science, Technology and the Environment, Malaysia.
} 
provided on the failure of the state government or the project proponent to replace the de-gazetted forest reserved area (The National Forestry Act, s12). The failure of replacement of the de-gazetted forest area indeed contributes to reduction in forest coverage. Thus, the principle on polluter pays is not in practice.

Another forest related legislation is the Environmental Impact Assessment (EIA). The EIA “...is a study to identify, predict, evaluate and communicate information about the impacts on the environment of a proposed project and to detail out the mitigating measures prior to project approval and implementation." (MNRE, 2012 and Sharom, 1998). Besides the appointment, the study or assessment conducted should fulfil the requirement of the report made by the DOE by having proper planning before and after the project towards preventing adverse environmental impact. The situation of EIA non-compliance has been frequently reported and the factors are said to be the loopholes in the law and regulation itself (Interview, 2012 and Leong, 1991). Thus, it is significant to note that, the final approval by the approving authority onto the project would only be given after the approval of the EIA report (Said, 1997).

Despite difficulties in dealing with forest issues in Peninsular Malaysia, Malaysia's approach to complying with the international arrangements has made the tangle much easier to unravel. For instance, the tsunami tragedy has proved the significant role played by mangroves in reducing wave impacts along coastal areas in some northern parts of Peninsular Malaysia (Ibrahim and Mohti, 2007). This can be considered as harm preventive strategy or action such as provided under the EIA. Thus, the coastal areas with mangroves, especially the Ramsar sites in Peninsular Malaysia, are now subject to a serious monitoring programme. Furthermore, additional mangrove plantation sites will soon benefit Malaysia in many aspects of environmental protection as well as enhancing biodiversity and preserving the organisms living therein.

Therefore, the EIA study is significant in avoiding potential damages or problems or even substantial cost in its implementation or reparation after the damage thus, in line with the environmental principle of the precautionary approach.

Another significant forest related policy is the National Policy on Biological Diversity (NPBD). The official declaration of the NPBD was proclaimed in Kuala Lumpur by the Ministry of Science, Environment and Technology, Malaysia, on 16 April 1998. Responding to the CBD, Malaysia has taken steps to devise its own policy on biodiversity which is concerned with conservation and sustainable management of biological diversity all over Malaysia.

The NPBD highlights that conservation and sustainable management should be for the purpose of developing the socio-economic wellbeing of the nation. The biological diversity issue in Malaysia will involve a number of agencies because water, land and forest are under the jurisdictions of different agencies under the state governments' control. Hence, the government should pursue a long-term national strategy to ensure biodiversity sustainability in Malaysia even though facing with scarce data (Latiff and MNRE, 2012).

Referring to the role of CBD in Malaysia's approach to protecting and conserving forest, it can be perceived that the clear guidelines have been underlined by the CBD for the Forestry Department to plan for flexible techniques and approaches to protection and preservation of forest. It is observed that Forestry Department has paid attention to preserving forests by categorizing specific forest areas to be maintained and sustained.

Pertaining to Malaysian Plans (MP) on forest, Table 1 shows the government's efforts in prioritizing forest conservation.

Table 1: The Government's Priority on Forest in Malaysia Plan

\begin{tabular}{|l|l|l|}
\hline $\begin{array}{l}\text { Malaysia Plan } \\
\text { (MP) }\end{array}$ & Forest Priority \\
\hline $\begin{array}{l}\text { The First MP } \\
(1966-1970)^{15}\end{array}$ & $\begin{array}{l}\text { The government emphasized economic and social development and progress in order to build an independent } \\
\text { nation; hence, environmental concerns were not a priority in this particular plan. }\end{array}$ \\
\hline $\begin{array}{l}\text { The Second } \\
(1971-1975)^{16}\end{array}$ & MP & $\begin{array}{l}\text { Forest was placed under Chapter IX - Agriculture, Forestry and Fishing. In that particular era there was a major } \\
\text { expansion and clearance of forested land in order to establish rubber, oil palm and kernel estates. However, the } \\
\text { government in that particular period made an effort to establish a Forest Research Laboratory in Kepong and a } \\
\text { Forest Institution for the purpose of forest matters and concerns. }\end{array}$ \\
\hline $\begin{array}{l}\text { The Third } \\
(1976-1890)^{17}\end{array}$ & MP & $\begin{array}{l}\text { A continuation of the previous plan where agriculture continued to play an important role in the economy and } \\
\text { forestry was still placed under the same Chapter of the previous plan. }\end{array}$ \\
\hline The Fourth MP & Forestry was placed under Chapter XV - Agriculture, Livestock, Fisheries and Forestry. \\
\hline
\end{tabular}

${ }^{15}$ Official Portal of Economic Planning Unit Prime Minister's Department Malaysia, 'First Malaysia Plan, 1966-1970' (1 June 2010) <http://www.epu.gov.my/first> accessed 1 March 2011. See also <http://pmr.penerangan.gov.my> accessed 1 March 2011.

${ }^{16}$ Official Portal of Economic Planning Unit Prime Minister's Department Malaysia, 'Second Malaysia Plan, 1971-1975' (1 June 2010) <http://www.epu.gov.my/second> accessed 1 March 2011.

${ }^{17}$ Third Malaysian Plan, 1976-1980 (Kuala Lumpur, Government Press, 1976). 
Adoption Of Environmental Principles In Forest Legislation Of Malaysia: An Appraisal

\begin{tabular}{|c|c|}
\hline $\begin{array}{l}\text { Malaysia } \quad \text { Plan } \\
(\text { MP) }\end{array}$ & Forest Priority \\
\hline \multicolumn{2}{|l|}{$(1981-1985)^{18}$} \\
\hline $\begin{array}{l}\text { The Fifth MP } \\
(1986-1990)^{19}\end{array}$ & $\begin{array}{l}\text { The government started to show more concern for forestry aspects in this was a continuation of the previous MP } \\
\text { and it attempted to redress socio-economic imbalances and eradicate poverty. }\end{array}$ \\
\hline $\begin{array}{l}\text { The Sixth } \mathrm{MP} \\
(1991-1995)^{20}\end{array}$ & $\begin{array}{l}\text { Forest was placed under the environment section of the plan and was no longer included among commodity } \\
\text { resources. The government's interest in conserving forest was seen in the next plan in which the National } \\
\text { Biodiversity Policy was launched in April } 1998 \text {. }\end{array}$ \\
\hline $\begin{array}{l}\text { The Seventh MP } \\
(1996-2000)^{21}\end{array}$ & Forest was placed under Chapter 19 in the Environment and Sustainable Resource Management section. \\
\hline $\begin{array}{l}\text { The Eighth MP } \\
(2001-2005)^{22}\end{array}$ & $\begin{array}{l}\text { Forest matters were placed under the same Chapter as the previous plan. This plan focused on the development and } \\
\text { progress of the country towards fully-developed nation status by the year } 2020 \text {. }\end{array}$ \\
\hline $\begin{array}{l}\text { The Ninth MP } \\
(2006-2010)^{23}\end{array}$ & $\begin{array}{l}\text { Started to emphasize preventive measures to reduce pollution by introducing environmental planning, i.e. } \\
\text { Environmental Impact Assessment (EIA) and also enhancement of Research and Development (R\&D). With regard } \\
\text { to forestry the government made several efforts to upgrade the status of forest conservation. }\end{array}$ \\
\hline $\begin{array}{l}\text { The Tenth } \\
(2011-2015)^{24}\end{array}$ & $\begin{array}{l}\text { Focuses on economic stability and social justice, with funding being allocated to physical development and non- } \\
\text { physical development on the basis of a 60/40 ratio. In this particular plan, forest has been placed under Chapter } 6- \\
\text { Building an Environment that Enhances Quality Of Life; the issue on conserving forests was underlined under } \\
\text { subchapter 6: Valuing the Nation's Environmental Endowments. }\end{array}$ \\
\hline
\end{tabular}

Thus, a number of the above-mentioned MPs have signified the importance of forest from an environmental perspective. It is apparent that the Fourth, Fifth, Ninth and Tenth MPs have highlighted the government's emphasis on dealing with the issue of forest conservation in Malaysia as compared to the other Malaysian Plans which mentioned the issue of the environment without specifically referring to forest conservation issues.

It is also can be seen that the endorsement of the National Forestry Policy during the Fourth Malaysia Plan was a significant indication that the government was becoming serious about forest conservation. Therefore all states in Peninsular Malaysia have accepted and adopted the Policy in their practice for the purpose of standardizing forest matters. Under this new policy, the Permanent Forest Estate (PFE) was introduced and this reflects the government's intention to reserve some parts of the forest for the purpose of conservation.

The Ninth Malaysia Plan had placed an emphasis on preventive measures to mitigate and minimize pollution. The application of relevant Environmental Planning Tools such as the Environmental Impact Assessment (EIA), Strategic Environmental Assessment (SEA), environmental auditing, etc has been highlighted in order to minimize the undesirable impact on the environment. Besides the application of related environmental tools, Research and Development with regard to forest will be strengthened. It also stressed the development of the Environmental Sensitive Areas (ESA) in meeting the needs of sustainable development.

Forest is placed under the Natural Resource Management part alongside other natural resources such as land, water, biodiversity, minerals, and marine and coastal areas. This particular part highlights the establishment of new three protected areas, Taman Negara DiRaja Belum (the Royal Belum), Taman Negara Pulau Pinang and Taman Warisan Selangor. The number of protected areas has now increased from 37 to 40 . Besides the establishment of Taman Negara, the establishment of forest plantations has also increased to 75,800 ha.

Malaysian forest management practices have already been influenced by what was agreed in Rio. This has been proved by the establishment of the country's own forest scheme which has been accredited by several developed countries and also by international and regional organisations. Accordingly, as of February 2012, the Forest Management Unit (FMU) has successfully maintained the forest certification by SIRIM QAS International Sdn Bhd and SGS (M) Sdn Bhd. There are currently eight FMUs in Peninsular Malaysia: Johor,

\footnotetext{
${ }^{18}$ Official Portal of Economic Planning Unit Prime Minister's Department Malaysia, Fourth Malaysia Plan, $1981-1985$ (1 June 2010 ) <http://www.epu.gov.my/fourth> accessed 1 March 2011.

${ }^{19}$ Fifth Malaysian Plan, 1986-1990 (Kuala Lumpur, National Printing Department, 1986).

${ }^{20}$ Official Portal of Economic Planning Unit Prime Minister's Department Malaysia, Sixth Malaysia Plan, 1990-1995 (1 June 2010) <http://www.epu.gov.my/sixth> accessed 1 March 2011.

${ }^{21}$ Official Portal of Economic Planning Unit Prime Minister's Department Malaysia, Seventh Malaysia Plan, $1996-2000$ (1 June 2010) <http://www.epu.gov.my/seventhmalaysiaplan> accessed 1 March 2011.

${ }^{22}$ Official Portal of Economic Planning Unit Prime Minister's Department Malaysia, Eighth Malaysia Plan, 2001-2005 (1 June 2010) <http://www.epu.gov.my/eightmalaysiaplan> accessed 1 March 2011.

${ }^{23}$ Malaysia, The Economic Planning Unit, Prime Minister's Department, The Ninth Malaysia Plan, 2006 -2010 (The Economic Planning Unit, Prime Minister's Department 2006).

${ }^{24}$ Official Portal of Economic Planning Unit Prime Minister's Department Malaysia, 'The Tenth Malaysia Plan' (10 ${ }^{\text {th }}$ MP) (1 June 2010) <http://www.epu.gov.my/rmkesepuluh> accessed 1 March 2011.
} 
Kedah, Kelantan, Negeri Sembilan, Pahang, Perak, Selangor and Terengganu and these cover 4.58 million ha of the Permanent Reserve Forests in Peninsular Malaysia (www.forestry.gov.my, 2014). For the states to be recognized as FMUs, they must be assessed by an independent third party according to the Malaysian Criteria and Indicators 2002 (MC\&I 2002). This practice has contributed to increased costs in terms of manpower and time as it requires particular improvement and enhancement in dealing with the assessment scheme. Nevertheless, this has shown high commitment and support of the Malaysian's government towards sustainability of forest. As reported in 2005, 67 companies have been given MC\&I certification for forest conservation efforts. This shows that private companies have also started to contribute to the effort besides the government and that forests are now beginning to be recognized as the world's heritage which needs to be sustained. Among other efforts also scheduled in the Ninth MP to help benefit the forest is the conservation and rehabilitation of mangrove forest; this plan was the outcome of the tsunami incidents of 2004. Thus, from the above facts it can be said that, through the Ninth MP, the government has made serious efforts to protect the forest besides other crucial issues in Malaysia.

The Tenth MP has shown concern over the issue of deforestation which was found to be responsible for approximately $20 \%$ of total global emissions of greenhouse gases (GHG) (Sim, 2007). Under this plan, the federal government has to ensure that forests in Malaysia are able to act as carbon sinks. The government has therefore encouraged all states to gazette their forests as protected areas, especially water catchment areas, and also to cooperate with the Non-Governmental Organisations in planting more trees to increase the amount of green space in the country. Local communities were also to be involved in order to upgrade their income and because local communities are the people who are closest to the forest, especially "Orang Asli".

\section{CONCLUSION}

From the above discussion, it is apparent that despite numerous forest programmes and strategies provided under the various National Plans, the Environmental Law principle has not been reflected in the primary forest legislation i.e. the National Forestry Policy and the National Forestry Act (the NFP and the NFA). Even though there is provision on sustainable forest management in the NFP, evidently forests in Peninsular Malaysia are kept reducing in number. The aforementioned National Plans also load with strategies and planning nevertheless, all these plans are not legally binding in its effect.

Furthermore, there are indeed major forest issues on which international and, especially, Malaysian legal instruments must focus in order to prevent our forest from being diminished. With respect to forest legal matters, the guardians of Malaysia's forest must be proactive in every suggestion and recommendation put forward by the international forest bodies and agreements, especially in ensuring that the forest legal mechanisms are sufficiently conclusive to carry out the function of protecting and efficiently managing Malaysia's forests. Amendments to and enhancement of forest law and policy of Malaysia are crucial and must be instigated as forest losses are becoming an international and major issue around the world and need prompt action.

Besides providing holistic legal measures for conserving forests, the Environmental Principles on forest conservation should be judiciously understood. The forest authority in particular should ensure that the existing forest law and policy conform to related Environmental Principles such as sustainable development, precautionary approach, 'polluter pays' and intergenerational equity. This is significant in the sense that the primary forest agenda should be one of environmental concern rather than merely seeking to ensure a sustainable forest for the purpose of sustaining states' revenues. Thus, it is vital to incorporate and and also to adopt the Environmental Law principles in the programmes and strategies of the forest legislation to ensuring forest sustainability in Peninsular Malaysia.

\section{REFERENCES}

[1] M.Y. Zakaria et al International Forest-Related Agreements and Sustainable Forest Management With Reference To Peninsular Malaysia, Proc. National Conference on the Management and Conservation of Forest Biodiversity in Malaysia, Putrajaya, 2007.

[2] H.C. Thang, "Towards Achieving Sustainable Forest Management in Peninsular Malaysia", (2002) 65 No.4 The Malaysian Forester.

[3] A. Yaakob, A Legal Analysis on Law and Policy on Conservation of Forest in Peninsular Malaysia, University of Malaya, Kuala Lumpur, Malaysia, $\mathrm{PhD}, 2014$.

[4] Green Facts -Green Fact Scientific Board, 'Facts on Health and the Environment' (5 May 2011), $<\mathrm{http} / / / \mathrm{www}$.greenfacts.org/en/forests/l-3/2-extent-deforestation.htm\#1p0> accessed 27 May 2011. The data for total forest area are as at 2005 .

[5] Food and Agriculture Organization of the United Nations, 'State of the World's Forests' (2011) <http:www.fao.org/docrep/013/i2000e/i2000e00.pdf> accessed 31 May 2011.

[6] MTC website, "What the National Forestry Act says...", 25.10.2005, 31.5.2011 <http://www.mtc.com.my. See also Mazwin Nik Anis, 'Burden of Proof Shifts Buyer Will Have To Show That Logs Are Legal' The Star, 19 Sept. 2007.

[7] P. Sands, and P. Galizzi, Eds., Documents in International Environmental Law (Cambridge University Press, 2004).

[8] J.F. McEldowney and Sharron, Environmental Law \& Regulation (Blackstone Press Limited, 2001)

[9] D. Sharma, "National Policy on Biodiversity: An NGO Perspective", Proceedings of the Conference on Biodiversity and National Development: Acheivements, Opportunities and Challenges, Ed. Yong, Hoi Sen, (Kuala Lumpur: Akademi Sains Malaysia, 2009). 
[10] M. Sheridan and L. Lavrysen, eds., Environmental Law Principles in Practice, (Bruylant, 2002).

[11] Department of Environment, Ministry of Science, Technology and Environment, Malaysia, Environmental Impact Assessment Guidelines For Forestry (Department of Environment 1998).

[12] Forestry Department, Peninsular Malaysia, Pemahaman Mengenai Pindaan Akta Perhutanan Negara 1984 dan Implikasi Perlaksanaannya, 18 June 2007 <http://www.forestry.gov.my>.

[13] S. Beder, The Nature of Sustainable Development, $2^{\text {nd }}$ Ed., (Scribe, Newham, Vic., 1996) <http://www.uow.edu.au/ sharonb/STS300/equity/meaning/integen.html> accessed 19 July 2012. See also Intergenerational Equity 19.7.2012 <http://www.uow.edu.au/ sharonb/STS300/equity/meaning/integen.html>.quoted in Beder.

[14] E.B. Weiss, In Fairness to Future Generations and Sustainable Development, 17 July $2012<\mathrm{http} / / / \mathrm{www}$.auilr.org/pdf/8/8-1-2.pdf>.

[15] Jabatan Perhutanan Semenanjung Malaysia, Manual Perhutanan 2003 Jilid I (Forest Manual) (Kuala Lumpur: Jabatan Perhutanan Semenanjung Malaysia, 2003).

[16] Annual Report 2007, (Forestry Department Peninsular Malaysia, Kuala Lumpur,2007).

[17] www.forestry.gov.my

[18] H. Said, "Guna Akta Atasi Kegiatan Pembalak Haram", Berita Harian 22 June 2007.

[19] Laws of Malaysia The Environmental Quality (Amendment) Act 2012 (Act A1441). See also Malaysia, Official website of Department of Environment, Ministry of Natural Resources and Environment, <http://www.doe.gov.my/portal/developer/eia/eiageneral-information/> accessed 4 September 2007. See also Department of Environment, Ministry of Natural Resources and Environment, Malaysia, A Handbook of Environmental Impact Assessment Guidelines (Department of the Environment 2007).

[20] A. Sharom, Understanding the Environmental Quality Act 1974 in Mimi Kamariah Majid (Ed.), Current Legal Problems in Malaysia (University Malaya Press, 1998).

[21] Interview with Deputy Director General (Development) of the Department of Environment (Putrajaya, 8 October 2012).

[22] Y.K. Leong, 'Environmental Impact Assessment and Conservation' in R Kiew (ed) The State of Nature Conservation in Malaysia, (Malaysian Nature Society 1991).

[23] A. M. Said, The Practice of Post-Monitoring and Audit in Environmental Impact Assessment in Malaysia, University of Wales Aberystwyth, UK, PhD, 1997.

[24] S. Ibrahim and A. Mohti, Post Tsunami events in Peninsular Malaysia: intensification of R\&D in mangrove establishment for coastal protection' in Braatz et al (Eds), The Regional Technical Workshop on Coastal Protection in the Aftermath Indian Ocean Tsunami: What role for forests and trees? (FAO 2007).

[25] A. Latiff, 'The Current Status of Biodiversity in Malaysia' PowerPoint slides <http://www.ukm.my/myc/pdf/workshop/DAY\%20ONE_SESSION1/Prof\%20Latiff.pdf> accessed 3 August 2012. See also Malaysia, Ministry of Natural Resources and Environment, 'National Biological Biodiversity Policy' PowerPoint slides <http://www.cbd.int/doc/meetings/nbsap/nbsapcbw-seasi-01/other/nbsapcbw-seasi-01-my-en.pdf> accessed 3 August 2012.

[26] L.L. Sim, 'Malaysia a Net 'Carbon Sink”, The Star (Kuala Lumpur, 14 December 2007). 